\title{
EFFECTS OF DIETARY VACHELIA KARROO LEAF MEAL INCLUSION ON MEAT QUALITY AND HISTOLOGICAL PARAMETERS IN PEDI BUCKS FED A SETARIA VERTICILLATA HAY-BASED DIET
}

\author{
BROWN, D. ${ }^{*}-\mathrm{NG}$ 'AMBI, J. W. \\ Department of Animal Science, School of Agricultural and Environmental Sciences, University \\ of Limpopo, Private Bag X1106, Sovenga 0727, Polokwane, South Africa \\ *Corresponding author \\ e-mail:db4010396@gmail.com
}

(Received $1^{\text {st }}$ Nov 2018; accepted 20 $0^{\text {th }}$ Dec 2018)

\begin{abstract}
The objective of this study was to investigate the effect of dietary Vachellia karroo leaf meal inclusion on growth performance, meat quality and histological parameters in bucks. A total of thirty yearling Pedi bucks with a mean initial body weight of $16.7 \pm 3.3 \mathrm{~kg}$ were randomly assigned to five treatments in a completely randomized design. Vachellia karroo leaf meal inclusion levels of 20, 25, 30, 40 and $50 \%$ were fed to the animals for 60 days. The results showed that dietary treatments had no effect on the final live weights and average daily gains of bucks. Similarly, yields of different carcass components and meat sensory attributes were not affected by the V. karroo. Bucks fed $25 \%$ V. karroo leaf meal had higher meat $L^{*}$ values than those on diets 30 or $40 \%$ inclusion levels. The livers of bucks fed 20,25 or $30 \%$ V. karroo leaf meal were not adversely affected. However, severe hepatocyte degeneration was noticed in the liver tissues of bucks fed 40 or $50 \%$ leaf meal. Dietary V. karroo did not cause any serious damage to the kidneys of the bucks. Thus, V. karroo leaf meal inclusion levels of 20 to $30 \%$ are recommended.
\end{abstract}

Keywords: goats, tannin, carcass characteristics, sensory evaluation, acacia

\section{Introduction}

Pedi goats in communal areas of Limpopo province, South Africa depend on Vachellia karroo (Acacia karroo) leaves, particularly during the dry season (Jamala et al., 2013). Vachellia karroo leaves contain high levels of extracted condensed tannins ranging from $55-110 \mathrm{~g} / \mathrm{kg} \mathrm{DM}$ and have potent antioxidant properties (Mokoboki et al., 2005; Moon et al., 2014). Antioxidant activity of these plants is attributed to their phenolic compound content (Velasco and Salinas, 2011). Antioxidant activity of plant extracts such as condensed tannins have positive effect on meat quality and oxidative stability (Moyo et al., 2012; Qwele et al., 2013). On the other hand, high condensed tannin contents in the diet negatively affect nutrient availability (Gxasheka et al., 2015). Reports on the effects of tanniferous diets on small ruminant productivity and meat quality are not conclusive. Some authors found that tannin-rich diets positively influence chevon quality (Priolo and Vasta, 2007; Mapiye et al., 2009; Marume, 2010; Bakare and Chimonyo, 2011; Ngambu et al., 2012, 2013), whereas, others found no clear evidence (Mapiye et al., 2010). Additionally, Vachellia karroo leaf meal inclusion levels for optimum Pedi bucks meat quality were not found in the literature.

Kidney and liver are vital organs in the animal's body and play vital role in the detoxification process. Dysfunction in liver and kidney may lead to diseases such as ascites and uremia (Karimi et al., 2014). Ruminants browsing on tanniferous forage have adapted rumen micro-organisms that detoxify many, but not all plant secondary 
metabolites (Cheeke, 1988). A large intake of tannins in the diet may cause kidney irritation and liver damage due to the detoxification process as a consequence of increased enzymatic demand (Van Soest, 1994; Mahgoub et al., 2008). Previous studies have reported a negative effect of condensed tannins on the histopathology of Boer goats (Mbatha et al., 2002). According to the authors, increased dietary tannin levels induced thickening and/or keratinization of epithelial tissue in the reticulum, rumen, omasum and abomasum. Increased tannin levels also resulted in a loss of epithelial cells, erosion of microvilli and shortened villi height in the duodenum (Mbatha et al., 2002). Karimi et al. (2014) reported histological changes in the kidney and liver parenchyma of GhezelxArkhar Merino crossbred lambs fed low tannin sorghum grain. Goats are predominantly browsers and they are able to consume large amounts of tannin-rich forage, which may increase the risk of exposure to sub-clinical systemic toxicity (Gilboa, 1995). Hence, monitoring of these organs in nutritional studies is imperative. There is paucity of information on the effect of tanniferous diets on the liver and kidney of goats. It is hypothesized that increased dietary tannin may result in variable damage of these organs. This study investigated the effects of Vachellia karroo leaf meal inclusion on meat quality and histology of livers and kidneys of Pedi bucks.

\section{Materials and methods}

\section{Study site}

The study was conducted at the University of Limpopo Experimental farm, South Africa (latitude $27.55^{\circ} \mathrm{S}$ and longitude $24.77^{\circ} \mathrm{E}$ ). The ambient temperatures at the study site range between 20 and $36^{\circ} \mathrm{C}$ during summer and between 5 and $25^{\circ} \mathrm{C}$ during winter. Mean annual rainfall is $446.8 \mathrm{~mm}$ with the dry season occurring between April and October and the rainy season occurring between November and March.

\section{Collection, drying and storage of plant material}

Vachellia karroo leaves were harvested during the summer months (NovemberJanuary). Branches of each shrub were removed manually and placed in a shed. Leaves were allowed to air dry on the branches and then removed by carefully beating the branches with sticks. The leaves were stored in air-tight bags until feeding time. Detailed reviews on the botanical description of $V$. karroo have been described by Barnes et al. (1996). Setaria verticillata (L.) P. Beauv. is a perennial grass belonging to the tribe Panacea and is widely grown by commercial farmers in Limpopo Province of South Africa. The grass is well grazed during summer and is suitable for hay making. Botanical authentication of the plant materials was done at the Larry Leach Herbarium, Department of Biodiversity, University of Limpopo.

\section{Animal, management, diet and experimental design}

All animal procedures were approved by the Animal Research Ethics Committee of the University of Limpopo, South Africa. A total of thirty yearling Pedi bucks (Capra hircus), (a local indigenous breed in Limpopo province of South Africa) with a mean initial body weight of $16.7 \pm 3.3 \mathrm{~kg}$ were randomly assigned to five treatments in a completely randomized design. Each treatment had three replicates with two goats per replicate. The animals were housed in individual holding pens $\left(1 \times 3 \mathrm{~m}^{2}\right)$ that were installed in a well ventilated shed with one side open to natural light and roofed to 
protect animals against the sun and rain. Yearling Pedi bucks were selected because they are the ones fattened for meat in the province. All animals were drenched with an anthelmintic (Valbazen ${ }^{\circledR}$ broad spectrum dewormer, manufactured by Pfizer Animal NY, USA) and sprayed with Diazintol ${ }^{\circledR}$ (Alfasan International, Holland) before the start of the experiment.. The goats were individually fed ad libitum once a day at 8:00 am, allowing a $15 \%$ refusal of each diet (Kaitho et al., 1996) and they had free access to clean water and a salt block. Prior to the trial, the animals were given the dietary treatment for $14 \mathrm{~d}$ ad libitum for adaptation, and the feeding trial lasted for $60 \mathrm{~d}$. The grass and $V$. karroo leaves were chopped and thoroughly mixed to avoid diet selection by the animals when fed (Table 1). Vachellia karroo leaf meal inclusion levels of 20, 25, 30, 40 and 50 were used in the present study. These inclusions include low and high tannin levels as indicated in the literature (Brown et al., 2017). Feed intake was recorded on a daily basis. Intake was calculated by subtracting leftovers from the feed given. Dry matter values of the feeds and feed refusals were determined. The goats were weighed three times, at the start of the experiment, on day 54 and on the $60^{\text {th }}$ day when data collection ended. Goats were weighed before morning feeding to avoid feed effect. Average daily gains were calculated as differences between final and initial body weights divided by number of feeding days.

Table 1. Feed composition of the experimental diets

\begin{tabular}{c|c|c}
\hline \multicolumn{3}{c}{ Diets } \\
\hline Diet code & Vachellia karroo $(\%)$ & Setaria verticillata hay $(\%)$ \\
\hline $\mathrm{V}_{20} \mathrm{~S}_{80}$ & 20 & 80 \\
$\mathrm{~V}_{25} \mathrm{~S}_{75}$ & 25 & 75 \\
$\mathrm{~V}_{30} \mathrm{~S}_{70}$ & 30 & 70 \\
$\mathrm{~V}_{40} \mathrm{~S}_{60}$ & 40 & 60 \\
$\mathrm{~V}_{50} \mathrm{~S}_{50}$ & 50 & 50 \\
\hline
\end{tabular}

Nutrient composition of V. Karroo and S. verticillata grass was previously reported by Brown and Ng'ambi (2017). The same applies to the nutritive values of dietary mixtures of the browse and grass hay used in the present study (Tables 2 and 3).

Table 2. Nutrient composition of Vachellia karroo leaves and Setaria verticilllata hay

\begin{tabular}{c|c|c}
\hline Nutrient & Vachellia karroo & Setaria verticillata hay \\
\hline Dry matter (g/kg) & 971 & 962 \\
Organic matter (g/kg DM) & 921 & 914 \\
Crude protein (g/kg DM) & 127 & 79 \\
Acid detergent fibre (g/kg DM) & 325 & 507 \\
Neutral detergent fibre (g/kg DM) & 380 & 779 \\
Condensed tannins (\%DM) & 2.0 & 0 \\
Total phenols (\%DM) $^{2}$ & 1.9 & 0 \\
\hline
\end{tabular}

${ }^{1}$ Condensed tannins as percentage DM leucocyanidin equivalent

${ }^{2}$ Expressed as tannic acid equivalent (\%) 
Table 3. Chemical composition of the dietary mixtures of Vachellia karroo leaves and Setaria verticillata grass hay

\begin{tabular}{c|c|c|c|c|c}
\hline \multicolumn{7}{c}{ Diet } \\
\hline Nutrient & $\mathbf{V}_{\mathbf{2 0}} \mathbf{S}_{\mathbf{8 0}}$ & $\mathbf{V}_{\mathbf{2 5}} \mathbf{S}_{\mathbf{7 5}}$ & $\mathbf{V}_{\mathbf{3 0}} \mathbf{S}_{\mathbf{7 0}}$ & $\mathbf{V}_{\mathbf{4 0}} \mathbf{S}_{\mathbf{6 0}}$ & $\mathbf{V}_{\mathbf{5 0}} \mathbf{S}_{\mathbf{5 0}}$ \\
\hline Dry matter (g/kg) & 952 & 958 & 940 & 952 & 970 \\
Organic matter (g/kg DM) & 915 & 915 & 916 & 916 & 917 \\
Crude protein (g/kg DM) & 89 & 91 & 93 & 98 & 103 \\
Acid detergent fibre (g/kg DM) & 470 & 461 & 452 & 433 & 415 \\
Neutral detergent fibre (g/kg DM) & 699 & 679 & 659 & 613 & 579 \\
Condensed tannins (\%DM) & 0.4 & 0.5 & 0.6 & 0.8 & 1.0 \\
Total phenols (\%DM) $^{2}$ & 0.3 & 0.4 & 0.5 & 0.7 & 0.9 \\
\hline
\end{tabular}

${ }^{1}$ Condensed tannins as percentage DM leucocyanidin equivalent

${ }^{2}$ Expressed as tannic acid equivalent (\%)

\section{Slaughter and carcass evaluation}

Prior to slaughter and muscle sample collection, the goats were fasted for $16 \mathrm{~h}$ with free access to drinking water and their body weight was recorded immediately after fasting. The animals were slaughtered humanely in the abattoir facility at the University Experimental Farm. The weights of the hot carcass and internal organs were recorded. The gastro-intestinal (GI) tract, including alimentary canal, reticulorumen and intestines were weighed after the removal of ruminal contents. Carcasses were chilled at $4{ }^{\circ} \mathrm{C}$ for $24 \mathrm{~h}$. After this period, cold carcass weight $(\mathrm{CCW})$ was determined.

\section{Meat quality determination}

The $\mathrm{pH}$ value at $1 \mathrm{~h}$ in Longissimus thoracic et lumborum muscle was measured after evisceration by using a $\mathrm{pH}$ meter equipped with a penetrating electrode (Crison $\mathrm{pH} 25$, CRISON instruments S. A., Alella, Spain). Before measurement, $\mathrm{pH}$ meter was calibrated with standard $\mathrm{pH}$ buffer ( $\mathrm{pH} 4.0,7.0$ and 10.0). At $24 \mathrm{~h}$ postmortem, the entire Longissimus thoracic et lumborum was removed for $\mathrm{pH}$, meat color and cooking loss. Meat color $\left(\mathrm{L}^{*}=\right.$ lightness, $\mathrm{a}^{*}=$ redness and $\mathrm{b}^{*}=$ yellowness $)$ was measured using a spectrophotometer with a D-65 illuminant and an aperture size of 50 mm (45/0 BYK-Gardener instrument GmbH, Germany). Before measurement, the spectrophotometer was calibrated with a white tile (model CR-A43). Three readings were taken by rotating the instrument $90^{\circ}$ between measurements, in order to obtain a representative average value of the color, and avoiding connective tissues and intramuscular fat. The readings were taken 1 and $24 \mathrm{~h}$ post-mortem. The meats were allowed to bloom for $1 \mathrm{~h}$ prior to color analysis.

For cooking loss analysis, blocks of longissimus thoracic et lumborum muscle, measuring approximately $7 \times 4 \times 4 \mathrm{~cm}$, were used to determine cooking loss (Babikerm et al., 1990) and shear force values (Chrystall et al., 1994). The muscle was weighed, placed in a water tight PVC plastic bag and cooked in a water bath at $85{ }^{\circ} \mathrm{C}$ for $45 \mathrm{~min}$, until an internal temperature of $70^{\circ} \mathrm{C}$ was attained. The samples were cooled and re-weighed. Cooking loss (CL) was calculated using the following 
formula: Cooking loss $\%=$ [(weight before cooking - weight after cooking) $/$ weight before cooking] $\times 100$ as described by Ding et al. (2010). After measurement of cooking loss, cooked samples were used to determine meat Warner Bratzler shear force. Three sub-samples (cut parallel to the muscle fibers with a cross-section of $1 \times$ $1 \mathrm{~cm}$ and at least $3 \mathrm{~cm}$ long) were removed from each cooked muscle. The subsamples were sheared perpendicular to the fiber direction with an Instron Universal Testing Machine (Model 3344, Instron Industrial Products, GC, USA) equipped with a Warner-Bratzler (WB) shear force apparatus (crosshead speed at $400 \mathrm{~mm} / \mathrm{min}$, one shear in the center of each core). The measurements were read in Newton. Dressing percentage was calculated as the ratio of hot carcass weight divided by slaughter body weight and the result multiplied by 100 . Water holding capacity (WHC) of the meat was measured as the amount of water expressed from a fresh meat sample $(1 \mathrm{~g})$ held under pressure $(60 \mathrm{~kg})$ using the filter-paper press method (Trout, 1988).

\section{Meat sensory evaluation}

Meat samples used for consumer sensory evaluation were obtained from each carcass and were cut $24 \mathrm{~h}$ post-slaughter. The meat samples were cut into cubes $(2 \times 2$ $\mathrm{cm}$ ), which were placed in watertight PVC plastic bags and cooked in a boiling water bath at a temperature of $85^{\circ} \mathrm{C}$ for 45 min (Babikerm et al., 1990). Salt was added to taste. Twenty trained consumer panelists from the University of Limpopo were used for the consumer sensory assessment of meat. Panelists were screened and selected following guidelines from Cross et al. (1978). The panelists were taught how to infer and record scores for each variable. The waiting period between meat sample tastings was $10 \mathrm{~min}$. Distilled water was served to panelists to freshen their mouths between sub-sample assessments to avoid crossover effects. Five-point descriptive scales were used to evaluate the sensory attributes (Table 4).

Table 4. Evaluation scores used by the sensory panel

\begin{tabular}{|c|c|c|c|c|c|c|}
\hline \multicolumn{7}{|c|}{ Sensory attribute } \\
\hline Score & Tenderness & Juiciness & Flavor & Taste & Aroma & $\begin{array}{c}\text { Overall } \\
\text { acceptability }\end{array}$ \\
\hline 1 & Too tough & Too dry & $\begin{array}{l}\text { Very bad } \\
\text { flavor }\end{array}$ & $\begin{array}{l}\text { Dislike } \\
\text { extremely }\end{array}$ & $\begin{array}{l}\text { Dislike } \\
\text { extremely }\end{array}$ & Dislike extremely \\
\hline 2 & Tough & Dry & Poor flavor & Dislike & Dislike & Dislike \\
\hline 3 & $\begin{array}{l}\text { Neither tough } \\
\text { nor tender }\end{array}$ & $\begin{array}{l}\text { Neither dry } \\
\text { nor juicy }\end{array}$ & $\begin{array}{l}\text { Neither bad nor } \\
\text { good }\end{array}$ & $\begin{array}{l}\text { Neither like } \\
\text { nor dislike }\end{array}$ & $\begin{array}{c}\text { Neither like } \\
\text { nor dislike }\end{array}$ & $\begin{array}{l}\text { Neither like nor } \\
\text { dislike }\end{array}$ \\
\hline 4 & Tender & Juicy & Good flavor & Like & Like & Like \\
\hline 5 & $\begin{array}{l}\text { Extremely } \\
\text { tender }\end{array}$ & $\begin{array}{l}\text { Extremely } \\
\text { juicy }\end{array}$ & $\begin{array}{l}\text { Very good } \\
\text { flavor }\end{array}$ & $\begin{array}{c}\text { Like } \\
\text { extremely }\end{array}$ & $\begin{array}{c}\text { Like } \\
\text { extremely }\end{array}$ & Like extremely \\
\hline
\end{tabular}

\section{Histological analysis}

Liver and kidney samples from each goat were collected and preserved in $10 \%$ neutral buffered formalin for $24 \mathrm{~h}$. Subsequently, liver and kidney tissues were dehydrated using standard histological techniques in graded ethanol series and embedded in paraffin wax for histopathology examination (Sanchez-Chardi et al., 2008). From each sample, 60-65 $\mu \mathrm{m}$ sections were cut and mounted on glass slides 
before staining with haematoxylin and eosin. Slides were examined under light trinocular microscopy at 400X (Leica Microsystems model DM750, Leica, Bannockburn, IL, USA). Each slide was photographed with a DVC digital camera (Digital Video Camera Company, Austin, TX) mounted on a BH-2. The process was as described by Sanchez-Chardi et al. (2009).

\section{Chemical analysis}

Dry matter, organic matter and crude protein were determined using the methods described by AOAC (2005). Neutral detergent fibre (NDF) and acid detergent fibre (ADF) were determined by the method of Van Soest (1994). Total phenolics were determined using Folin-Ciocalteau methods and expressed as tannic acid equivalent (\% DM) (Water and Mole, 1994). Condensed tannins were determined using the Butanol-HCl method and expressed as leucocyanidin equivalent (\%DM) (Porter et al., 1986). For each measurement, duplicate analyses were done.

\section{Statistical analysis}

Statistical analysis was performed using the GLM procedure of SAS (SAS, 2010). Initial live weight was fitted as covariate for carcass traits. The data are expressed as the mean \pm SEM and analyzed using one-way analysis of variance (ANOVA). Fisher's Protected Least Significant Difference (LSD) test was used for the post hoc analyses. A P $<0.05$ was considered statistically significant for all data.

\section{Results}

\section{Nutrient composition of Vachellia karroo and Seteria verticillata grass hay}

Vachellia karroo contained $127 \mathrm{~g} \mathrm{CP} / \mathrm{kg}$ DM and $921 \mathrm{~g} \mathrm{OM} / \mathrm{kg} \mathrm{DM}$. It also contained phenolic compounds. Seteria verticillata grass hay contained 79, 779 and $507 \mathrm{~g}$ of $\mathrm{CP}, \mathrm{NDF}$ and $\mathrm{ADF} / \mathrm{kg} \mathrm{DM}$, respectively. Setaria verticillata hay has no traces of phenolic compounds (Table 2). The nutritive values of dietary mixtures of $V$. karroo and $S$. verticillata hay are presented in Table 3. Diet containing 50\% V. karroo leaf meal contained $103 \mathrm{~g} \mathrm{CP} / \mathrm{kg}$ DM. The condensed tannin and total phenolic contents were 1.0 and $0.9 \%$, respectively. A diet containing $20 \% \mathrm{~V}$. karroo leaf meal inclusion had $89 \mathrm{~g} \mathrm{CP} / \mathrm{kg} \mathrm{DM}, 0.4 \%$ condensed tannin and $0.3 \%$ total phenolic content.

\section{Feed intake and growth performance}

Daily dry matter intakes were similar $(\mathrm{P}>0.05)$ across the dietary treatments, ranging from 638 to $786 \mathrm{~g}$ per goat. Similarly, goats consumed the same $(\mathrm{P}>0.05)$ daily amounts of organic matter $(\mathrm{OM})$, crude protein $(\mathrm{CP})$, neutral detergent fibre (NDF) and acid detergent fibre (ADF) contents. Vachellia karroo inclusion did not $(\mathrm{P}>0.05)$ affect the final body weights and average daily gains of goats (Table 5).

\section{Slaughter performance and internal organ weight of bucks}

As shown in Table 6, dietary $V$. karroo leaf meal inclusion had no effect $(\mathrm{P}>0.05)$ on hot and cold carcass weights of bucks. Similarly, the internal organ weights of bucks were not affected $(\mathrm{P}>0.05)$ by the dietary treatments. 
Table 5. Effect of Vachellia karroo leaf meal inclusion level on diet intake and growth performance of yearling Pedi bucks fed a Setaria verticillata grass hay-based diet

\begin{tabular}{c|c|c|c|c|c|c|c}
\hline \multirow{2}{*}{ Variable } & \multicolumn{5}{|c|}{ Treatment } & \multirow{2}{*}{ SEM } & \multirow{2}{*}{$\boldsymbol{P}$ value } \\
\cline { 2 - 5 } & $\mathbf{V}_{\mathbf{2 0}} \mathbf{S}_{\mathbf{8 0}}$ & $\mathbf{V}_{\mathbf{2 5}} \mathbf{S}_{\mathbf{7 5}}$ & $\mathbf{V}_{\mathbf{3 0}} \mathbf{S}_{\mathbf{7 0}}$ & $\mathbf{V}_{\mathbf{4 0}} \mathbf{S}_{\mathbf{6 0}}$ & $\mathbf{V}_{\mathbf{5 0}} \mathbf{S}_{\mathbf{5 0}}$ & & \\
\hline Intake (g/goat/day) & & & & & & & \\
Dry matter & 752 & 786 & 638 & 661 & 686 & 70.3 & 0.526 \\
Organic matter & 688 & 720 & 585 & 606 & 630 & 64.5 & 0.531 \\
Crude protein & 66 & 72 & 59 & 64 & 70 & 6.83 & 0.647 \\
NDF & 525 & 533 & 421 & 409 & 397 & 45.9 & 0.135 \\
ADF & 353 & 362 & 288 & 286 & 285 & 31.5 & 0.232 \\
Initial body weight (kg) & 16.0 & 17.3 & 13.7 & 16.1 & 15.2 & 2.55 & 0.815 \\
Final body weight (kg) & 22.8 & 24.1 & 21.4 & 23.8 & 24.6 & 2.61 & 0.800 \\
Average daily gain (g) & 113 & 114 & 129 & 129 & 157 & 23.8 & 0.204 \\
\hline
\end{tabular}

SEM: Standard error of the means; NDF: Neutral detergent fiber; ADF: Acid detergent fiber

Table 6. Effects of Vachellia karroo leaf meal inclusion level on slaughter performance and internal organ weight of bucks fed a Setaria verticillata grass hay-based diet

\begin{tabular}{c|c|c|c|c|c|c|c}
\hline \multirow{2}{*}{ Variable } & \multicolumn{5}{|c|}{ Treatment } & \multirow{2}{*}{ SEM } & \multirow{2}{*}{$\boldsymbol{P}$ value } \\
\cline { 2 - 6 } & $\mathbf{V}_{\mathbf{2 0}} \mathbf{S}_{\mathbf{8 0}}$ & $\mathbf{V}_{\mathbf{2 5}} \mathbf{S}_{\mathbf{7 5}}$ & $\mathbf{V}_{\mathbf{3 0}} \mathbf{S}_{\mathbf{7 0}}$ & $\mathbf{V}_{\mathbf{4 0}} \mathbf{S}_{\mathbf{6 0}}$ & $\mathbf{V}_{\mathbf{5 0}} \mathbf{S}_{\mathbf{5 0}}$ & & \\
\hline Pre-slaughter weight (kg) & 22.8 & 24.1 & 21.4 & 23.8 & 24.6 & 1.61 & 0.686 \\
Hot carcass weight (kg) & 7.8 & 8.3 & 6.9 & 8.2 & 8.9 & 0.64 & 0.361 \\
Cold carcass weight (kg) & 7.4 & 7.8 & 6.1 & 7.1 & 8.0 & 0.57 & 0.196 \\
Head (g) & 1882.3 & 1888.9 & 1772.8 & 1706.8 & 1987.3 & 141.8 & 0.674 \\
Skin (g) & 2092.2 & 2459.9 & 2328.3 & 2399.1 & 2486.3 & 210.8 & 0.695 \\
Feet (g) & 635.1 & 640.7 & 636.9 & 636.2 & 667.2 & 34.1 & 0.341 \\
Kidney (g) & 71.9 & 76.4 & 60.9 & 65.8 & 66.6 & 5.36 & 0.350 \\
Liver (g) & 310.0 & 334.8 & 275.8 & 286.8 & 284.8 & 24.87 & 0.487 \\
Lung (g) & 177.5 & 226.9 & 230.3 & 227.7 & 219.9 & 17.78 & 0.261 \\
Heart (g) & 106.6 & 96.8 & 96.0 & 96.4 & 119.3 & 8.01 & 0.218 \\
Genital scrotum (g) & 177.8 & 215.2 & 165.1 & 179.6 & 143.9 & 27.2 & 0.493 \\
Empty alimentary canal (g) & 1722.8 & 1449.7 & 1432.5 & 1792.7 & 1403.3 & 139.7 & 0.223 \\
Empty reticulo-rumen (g) & 585.0 & 543.8 & 458.8 & 555.8 & 446.6 & 52.6 & 0.310 \\
Empty intestine (g) & 790.8 & 561.2 & 636.6 & 862.9 & 544.0 & 92.5 & 0.125 \\
\hline
\end{tabular}

SEM: Standard error of the means

\section{Meat quality and consumer acceptability}

As shown in Table 7, there was no observed effect of dietary V. karroo leaf meal inclusion on the $\mathrm{pH}_{1 \mathrm{~h}}$ and $\mathrm{pH}_{24}$ h. Dietary $V$. karroo did not affect $(\mathrm{P}>0.05)$ the meat color $1 \mathrm{~h}$ post-mortem, water holding capacity, shear force, cooking loss and dressing percentage. However, there was treatment effect on meat color at $24 \mathrm{~h}$ post-mortem. Goats fed $25 \%$ V. karroo leaf meal had higher $(\mathrm{P}<0.05) \mathrm{L}^{*}$ intensity than those on diets 30 or $40 \%$ inclusion levels. On average, no differences $(\mathrm{P}>0.05)$ existed among treatments with respect to tenderness, juiciness, flavor, taste, aroma and overall acceptability (Table 8). 


$$
\text { - } 2900 \text { - }
$$

Table 7. Effect of Vachellia karroo leaf meal inclusion level on meat quality of bucks fed a Setaria verticillata grass hay-based diet

\begin{tabular}{c|c|c|c|c|c|c|c}
\hline \multirow{2}{*}{ Variable } & \multicolumn{5}{|c|}{ Treatment } & \multirow{2}{*}{ SEM } & \multirow{2}{*}{$\boldsymbol{P}$ value } \\
\cline { 2 - 6 } & $\mathbf{V}_{\mathbf{2 0}} \mathbf{S}_{\mathbf{8 0}}$ & $\mathbf{V}_{\mathbf{2 5}} \mathbf{S}_{\mathbf{7 5}}$ & $\mathbf{V}_{\mathbf{3 0}} \mathbf{S}_{\mathbf{7 0}}$ & $\mathbf{V}_{\mathbf{4 0}} \mathbf{S}_{\mathbf{6 0}}$ & $\mathbf{V}_{\mathbf{5 0}} \mathbf{V}_{\mathbf{5 0}}$ & & \\
\hline Muscle $\mathrm{pH}$ & & & & & & & \\
$\mathrm{pH}_{1}$ & 6.9 & 6.9 & 6.9 & 6.7 & 6.6 & 0.202 & 0.673 \\
$\mathrm{pH}_{24}$ & 5.9 & 5.9 & 5.7 & 5.8 & 5.9 & 0.156 & 0.744 \\
\hline Meat color 1 h post-mortem & & & & & & & \\
$\mathrm{L}^{* 1}$ & 34.4 & 27.6 & 29.7 & 28.0 & 25.0 & 2.244 & 0.120 \\
$\mathrm{a}^{* 2}$ & 14.8 & 17.4 & 15.3 & 15.9 & 18.1 & 1.555 & 0.547 \\
$\mathrm{~b}^{* 3}$ & 6.9 & 6.9 & 6.5 & 5.7 & 5.7 & 0.613 & 0.503 \\
\hline Meat color 24 h post-mortem & & & & & & & \\
$\mathrm{L}^{* 1}$ & $34.2^{\mathrm{ab}}$ & $37.3^{\mathrm{a}}$ & $27.2^{\mathrm{b}}$ & $29.2^{\mathrm{b}}$ & $33.6^{\mathrm{ab}}$ & 2.295 & 0.041 \\
$\mathrm{a}^{* 2}$ & 16.4 & 15.6 & 20.1 & 17.6 & 15.1 & 2.071 & 0.493 \\
$\mathrm{~b}^{* 3}$ & 8.3 & 6.7 & 10.9 & 6.5 & 7.9 & 1.730 & 0.421 \\
\hline Wnitial & & & & & & & \\
Final & 13.6 & 13.2 & 12.9 & 12.1 & 12.1 & 1.993 & 0.294 \\
Shear force (N) & 13.1 & 12.8 & 12.3 & 11.7 & 11.5 & 1.963 & 0.308 \\
Cooking loss (\%) & 36.6 & 35.1 & 31.4 & 31.8 & 33.3 & 4.729 & 0.920 \\
Dressing percentage & 38.2 & 38.0 & 35.7 & 37.7 & 40.3 & 1.799 & 0.449 \\
\hline
\end{tabular}

a,b Means with different superscripts in the same row are significantly different $(\mathrm{P}<0.05)$

SEM: Standard error of the means

${ }^{1}$ Lightness

${ }^{2}$ Red intensity

${ }^{3}$ Yellow intensity

Table 8. Consumer acceptability of meat from bucks fed dietary mixture of Vachellia karroo and Setaria verticillata grass hay

\begin{tabular}{c|c|c|c|c|c|c|c}
\hline \multirow{2}{*}{ Sensory characteristic } & \multicolumn{5}{|c|}{ Treatment } & \multirow{2}{*}{ SEM } & \multirow{2}{*}{$\boldsymbol{P}$ value } \\
\cline { 2 - 6 } & $\mathbf{V}_{\mathbf{2 0}} \mathbf{S}_{\mathbf{8 0}}$ & $\mathbf{V}_{\mathbf{2 5}} \mathbf{S}_{\mathbf{7 5}}$ & $\mathbf{V}_{\mathbf{3 0}} \mathbf{S}_{\mathbf{3 0}}$ & $\mathbf{V}_{\mathbf{4 0}} \mathbf{S}_{\mathbf{6 0}}$ & $\mathbf{V}_{\mathbf{5 0}} \mathbf{S}_{\mathbf{5 0}}$ & & \\
\hline Tenderness & 3.18 & 3.22 & 3.83 & 3.09 & 3.41 & 0.345 & 0.553 \\
Juiciness & 3.01 & 3.25 & 3.46 & 2.77 & 3.07 & 0.358 & 0.662 \\
Flavor & 3.15 & 3.29 & 3.59 & 3.46 & 3.51 & 0.305 & 0.802 \\
Taste & 3.21 & 3.34 & 3.55 & 3.64 & 3.51 & 0.305 & 0.852 \\
Aroma & 3.16 & 3.20 & 3.55 & 3.49 & 3.35 & 0.286 & 0.792 \\
Overall acceptability & 3.26 & 3.49 & 3.84 & 3.63 & 3.40 & 0.322 & 0.676 \\
\hline
\end{tabular}

SEM: Standard error of the means 


\section{Effect of dietary Vachellia karroo on histological changes in the liver and kidney tissues of bucks}

Histological analysis of the liver tissues of bucks fed 20, 25 or 30\% Vachellia karroo leaf meal showed moderate hepatocellular hydropic degeneration, dilation of central veins and proliferation of sinusoidal kupfer cells (Fig. la, $b$ and $c$, respectively). The hepatocytes of bucks fed diets containing 40 or $50 \% \mathrm{~V}$. karroo leaf meal had severe hepatocellular hydropic degeneration with multifocal single cell and clustered cell necrosis (Fig. $1 d$ and $e$, respectively). The kidney tissues of bucks fed 20, 25 or $30 \% \mathrm{~V}$. karroo leaf meal had early dilatation of glomerular uriniferous spaces and mild renal tubular nephrosis (Fig. $2 a, b$ and $c$, respectively), while those fed 40 or $50 \%$ V. karroo leaf meal had dilatation of uriniferous spaces and ectasia of some proximal convoluted tubules (Fig. $2 d$ and $e$, respectively). Intra-tubular proteinaceous fluids with protein cast formation were also noticed in the kidney of bucks on diets 40 or $50 \% \mathrm{~V}$. karroo leaf meal.

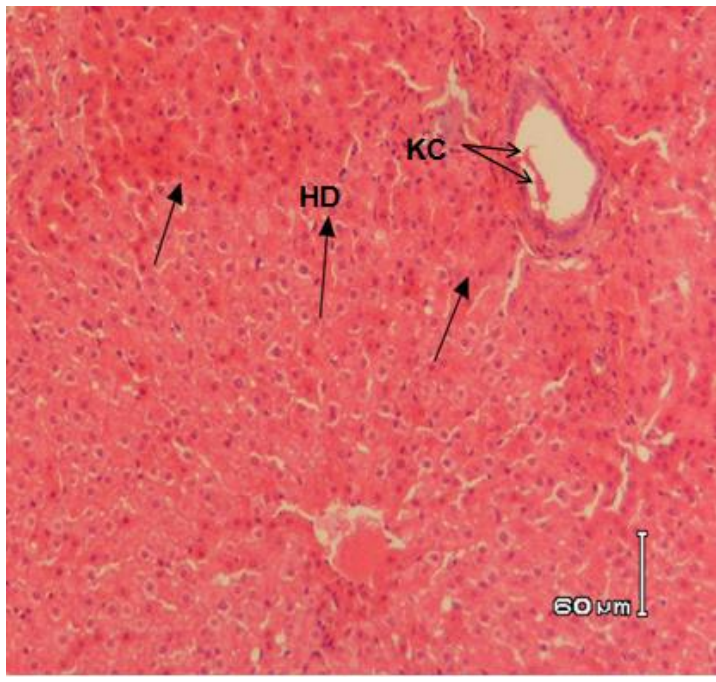

$\mathbf{a}$

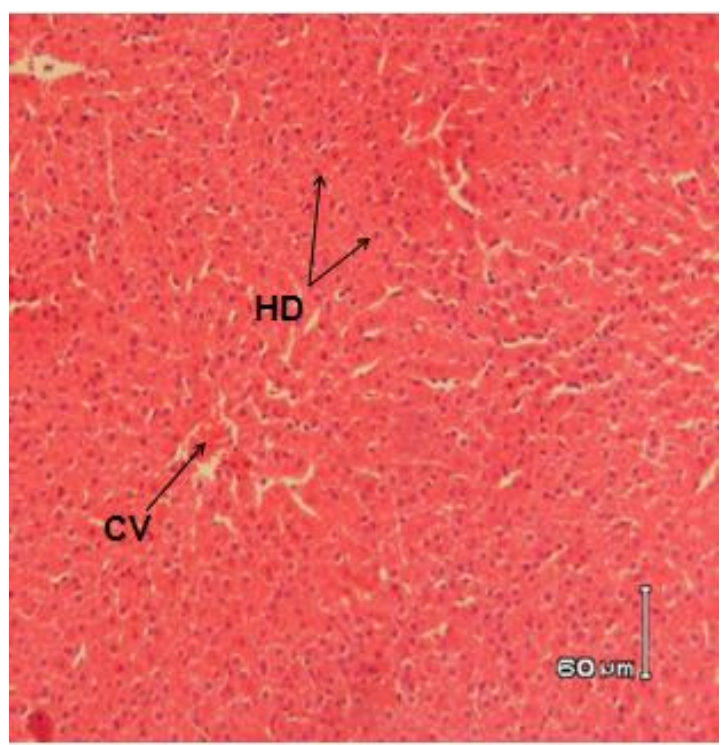

c

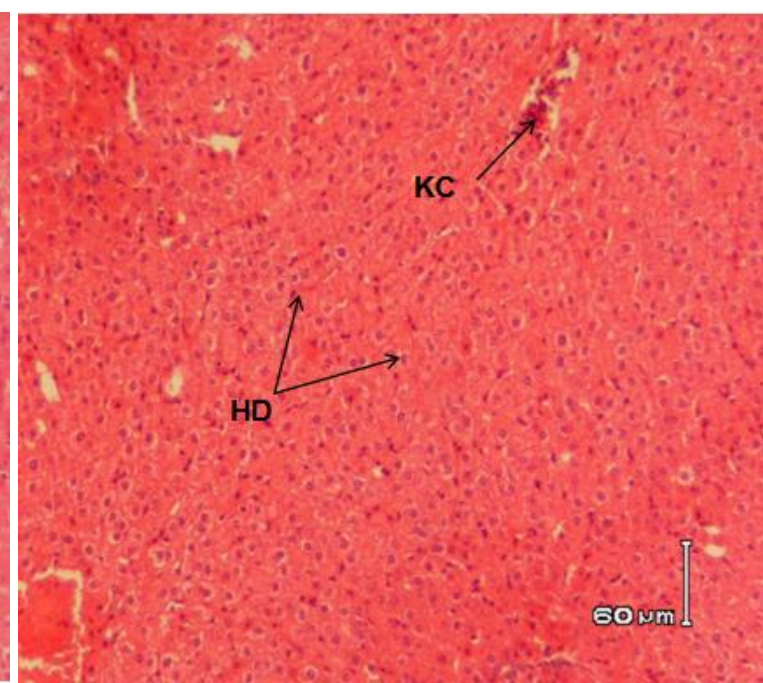

b

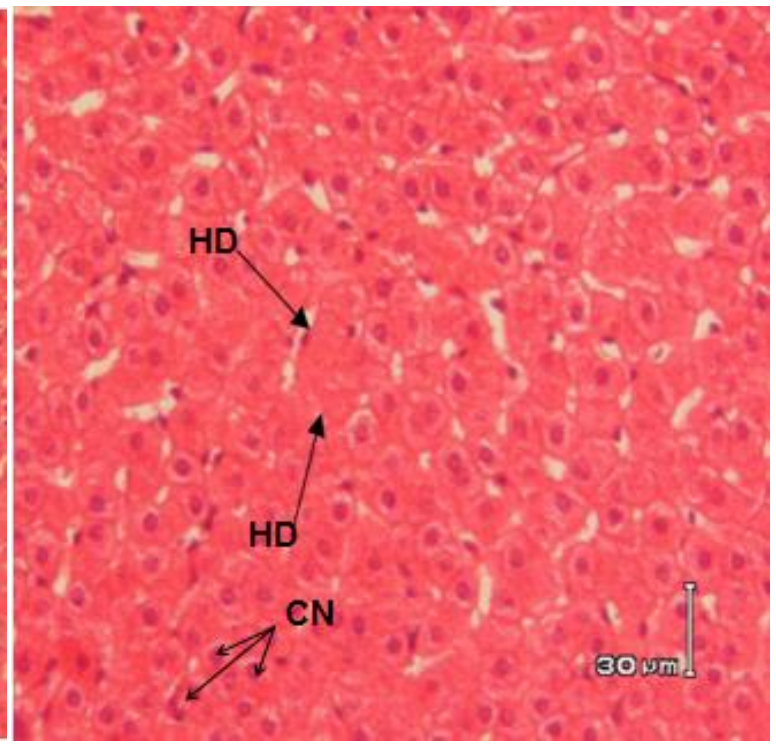

d 


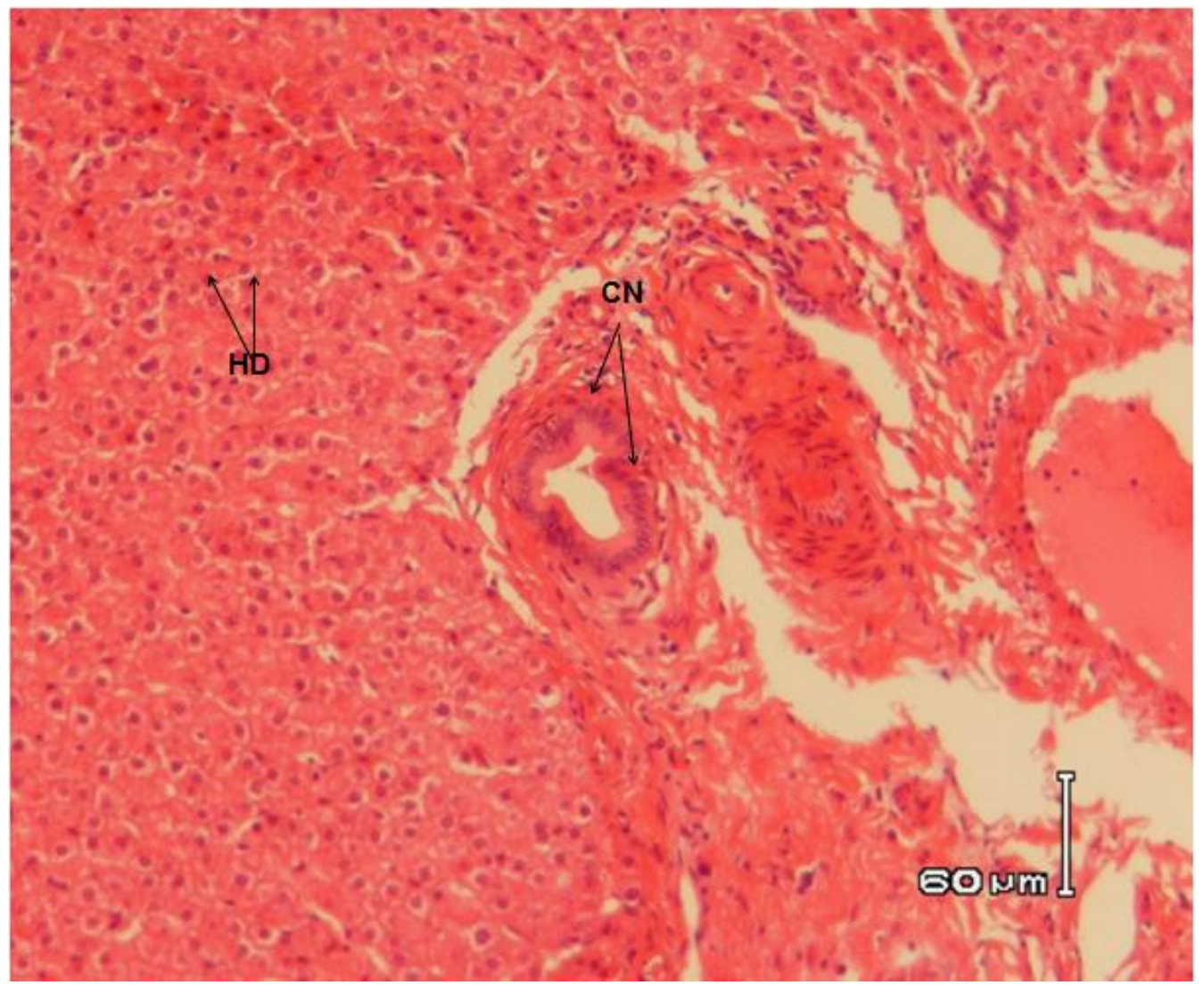

e

Figure 1. Effect of V. karroo leaf meal inclusion on liver histology of bucks. a Moderate hepatocellular hydropic degeneration and proliferation of sinusoidal kupfer cells $(20 \% \mathrm{~V}$. karroo). $\boldsymbol{b}$ Moderate hepatocellular hydropic degeneration and proliferation of sinusoidal kupfer cells (25\% V. karroo). c Moderate hepatocellular hydropic dilatation of central veins (30\% V. karroo). d Severe hepatocyte degeneration and multifocal single cells (40\% V. karroo). $\boldsymbol{e}$ Severe hepatocyte degeneration, multifocal single cell and clustered cell necrosis $(50 \% \mathrm{~V}$. karroo). Arrows point to hepatocellular hydropic degeneration (HD), kupfer cells (KC), central veins $(C V)$ and cell necrosis $(C N)$

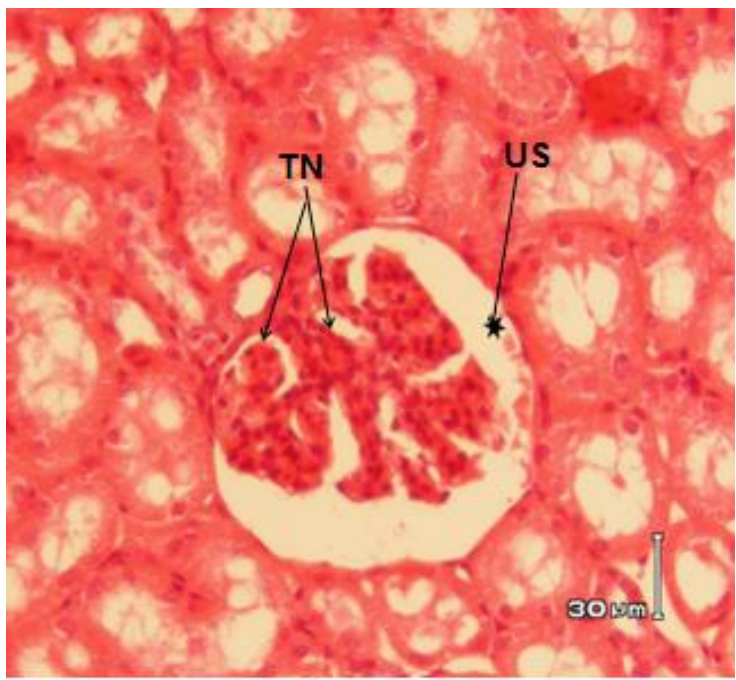

a

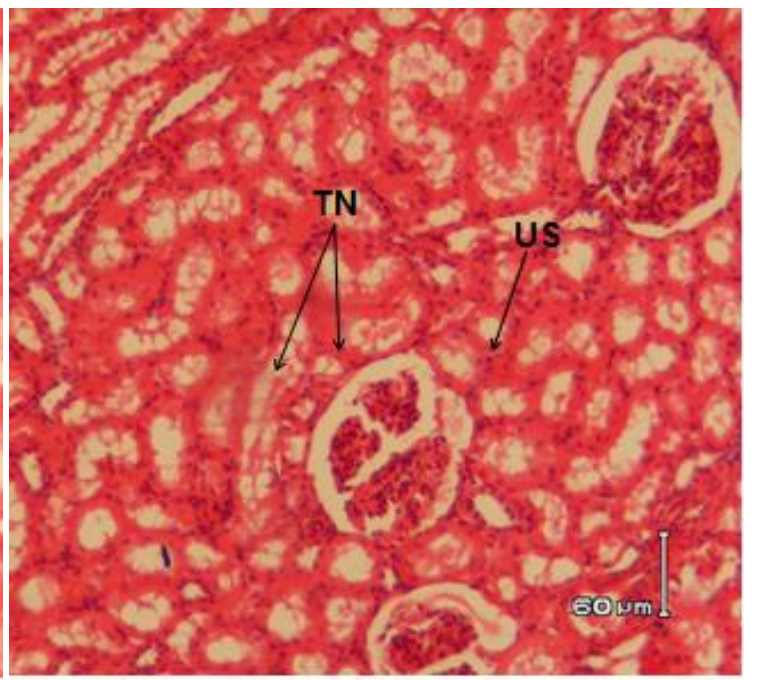

b

APPLIED ECOLOGY AND ENVIRONMENTAL RESEARCH 17(2):2893-2909.

http://www.aloki.hu • ISSN 15891623 (Print) • ISSN 17850037 (Online)

DOI: http://dx.doi.org/10.15666/aeer/1702_28932909

(c) 2019, ALÖKI Kft., Budapest, Hungary 


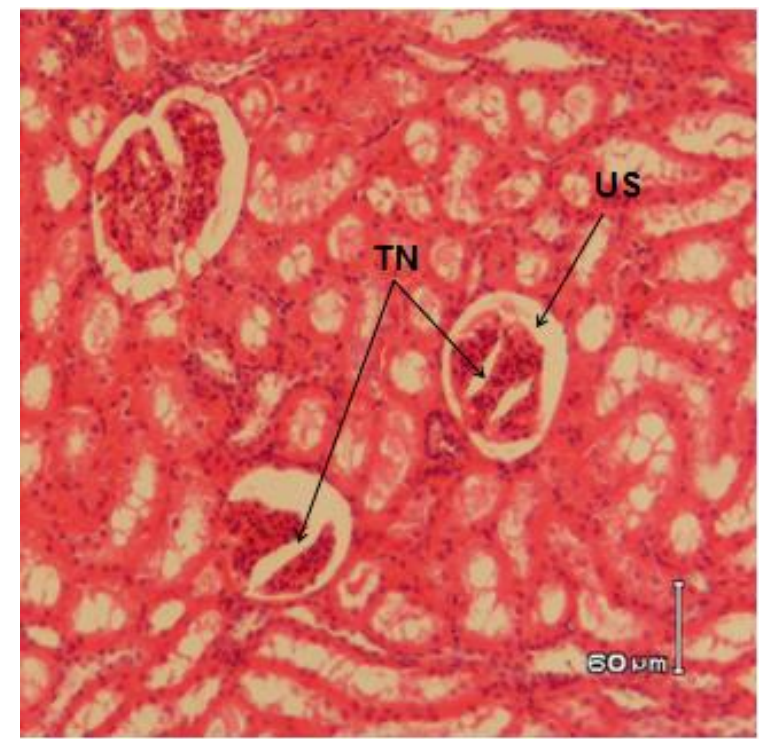

c

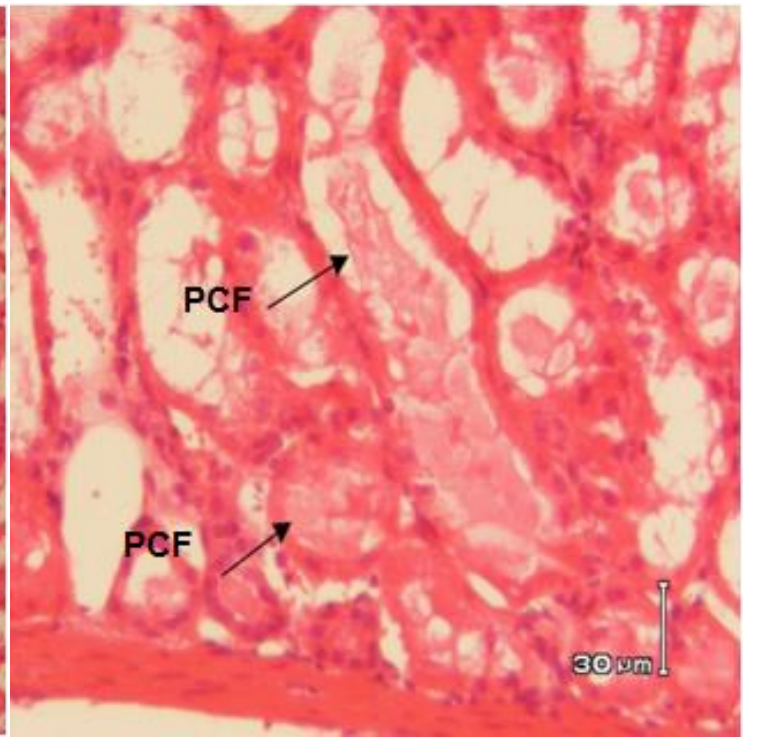

d

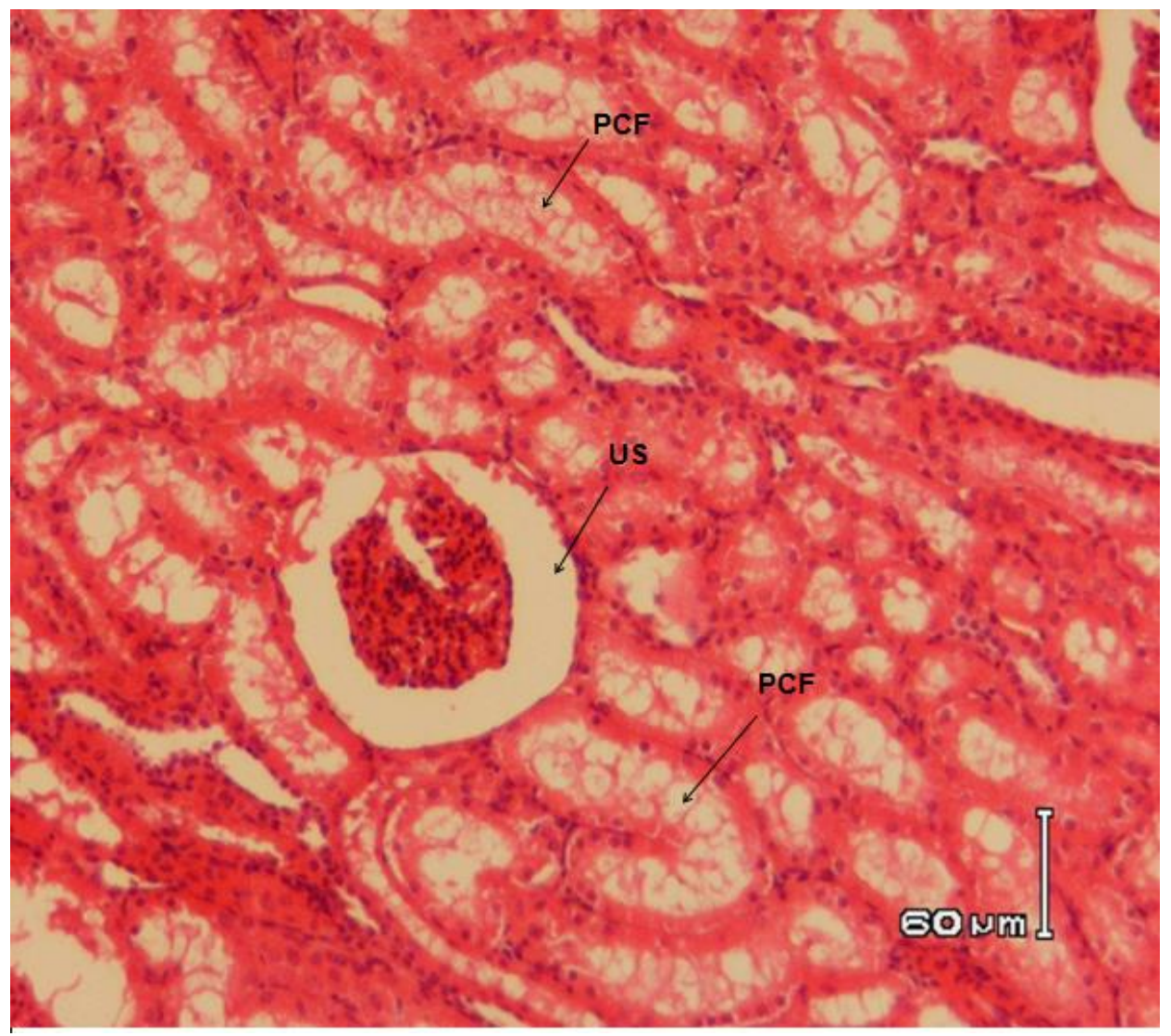

e

Figure 2. Effect of V. karroo leaf meal inclusion on kidney histology of Pedi bucks. a Early dilatation of glomerular uriniferous space and mild renal tubular nephrosis (20\% V. karroo). $\boldsymbol{b}$ Dilatation of glomerular uriniferious spaces and mild to moderate renal tubular nephrosis (25\% V. karroo). c Dilatation of uriniferous spaces, moderate renal tubular nephrosis (30\% V. karroo). $\boldsymbol{d}$ Dilatation of uriniferous spaces, intra-tubular proteinaceous fluid with protein cast formation (40\% V. karroo). e Dilatation of uriniferous space, intra-tubular proteinaceous fluid with protein cast formation. Arrows points to tubular nephrosis (TN), uriniferous space (US) and protein cast formation (PCF) 


\section{Discussion}

In the present study, V. karroo inclusion had no effect on diet intake of bucks. Similar results were reported for kids fed tanninferous Ageritum conyzoides, Eupotarium odoratum and Crystellina parasitica (Das et al., 2011). It has also been reported elsewhere that diets high in CT reduce intake of goats (Holechek et al., 1990). On the contrary, Solaiman et al. (2010) reported increased feed intake in Kiko crossbred male kids fed CT forage (Sericea lespedeza). Condensed tannins in forage legumes adversely affect feed intake through astringency in the oral cavity (Lamy et al., 2011). However, in the present study, diets with higher levels of CT were well-tolerated by goats. This may be due to the fact that the goats developed mitigatory systems against tannin toxicity such as secretion of proline-rich proteins in their saliva or proliferation of microorganisms resistant to condensed tannins in their digestive tracts (Lamy et al., 2011; Muir, 2011).

Dietary treatment did not improve growth performance of Pedi bucks. This is similar to the findings of Dludla (2010) who reported no differences in body weight gain of goats fed forages with different tannin concentrations. Wright (2015) observed similar results in Kiko-cross goats fed tanninferous Sericea lespedeza, pine bark powder and combination of Sericea lespedeza and pine bark powder. However, Ngambu et al. (2013) reported improved growth performance when Xhosa lop-eared goats were supplemented with $200 \mathrm{~g}$ of fresh $V$. karroo leaves. The lack of significant differences in body weight gain in the present study could be due to the fact that the dietary treatments met the nutrient requirements for a growing goat and hence nutrient supply was adequate for growth (McDonald et al., 2011).

Vachelia karroo leaf meal inclusion had no effect on the carcass weight and yields of Pedi bucks. Wright (2015) reported similar finding in Kiko-cross goats fed Sericea lespedeza, pine bark powder and combination of Sericea lespedeza and pine bark powder. The result obtained in the present study was expected since the dietary treatments did not influence average daily weight gains of goats.

According to Priolo et al. (2001), meat $\mathrm{pH}$ values can be influenced by dietary treatments. In the present study, V. karroo leaf meal inclusion had no effect on meat $\mathrm{pH}$ values. Previous studies demonstrated that the consumption of tanninferous feeds had no effect on chevon pH (Mapiye et al., 2010). However, Ngambu et al. (2013) observed significant differences in meat $\mathrm{pH}$ when goats were supplemented with $\mathrm{V}$. karroo leaf meal. The discrepancies in the results could be due to the amount of dietary tannins ingested by the animals in each study. The ultimate $\mathrm{pH}\left(\mathrm{pH}_{\mathrm{u}}\right)$ of a carcass usually varies from 5.3 to 6.8 (Mostert, 2007). Under-nutrition is a primary cause of high $\mathrm{pH}_{\mathrm{u}}$ in meats since animals do not have the possibility to accumulate sufficient glycogen reserve in their muscles (Bray et al., 1989). However, the experimental diets in the present study met the nutrient requirements for a growing goat and hence differences in meat $\mathrm{pH}$ values were not expected. Additionally, animals stressed prior to death are more likely to have a high $\mathrm{pH}_{\mathrm{u}}$. This is due to depletion of muscle glycogen resulting in lower lactic acid production. The animals in this study were not stressed prior to slaughter.

The present study indicated that goats fed $25 \% \mathrm{~V}$. karroo leaf meal produced meat which was lighter than those on diets 30 or $40 \%$ leaf meal. Normally, consumers prefer lighter meat than dark meat. Verna et al. (1989) found similar result when lambs were fed two sorghum varieties with different tannin contents. Effect of tanninferous feed on meat lightness have also been reported by other authors (Priolo et al., 2001). It has been hypothesized that tannins present in forages are responsible for the differences found in 
meat color (Priolo et al., 2005). The effect of tannins on meat color is attributed to the reduced microbial biosynthesis of vitamin $B_{12}$ (Priolo and Vasta, 2007). An increase in intramuscular and marbling fat is another factor that contributes to meat lightness (Baublits et al., 2004). However, the mechanism of action of forage tannins on meat color is not clear and merits further studies.

Dietary treatments had no effect on water holding capacity, shear force, cooking loss and dressing percentage of buck meat. These findings are similar to the report of Mapiye et al. (2010) who reported that beef from steers supplemented with V. karroo leaves had no effect on shear force, WHC, and cooking loss. Further research is needed to deepen the knowledge in this area. Meat sensory attribute values were also similar across the dietary treatments. Ngambu et al. (2012) however reported significant differences in consumer sensory attributes of meat from indigenous Xhosa lop-eared goat breed supplemented with different amounts of $V$. karroo leaves. It is not clear how dietary tannins affect the sensory attributes of goat meat and this may require further studies.

The liver is a primary site of detoxification and is generally the major site of intensive metabolism, hence, it is prone to various disorders as a consequence of exposure to toxins (Ganong, 2005). In the present study, goats fed 20, 25 or $30 \% \mathrm{~V}$. karroo leaf meal inclusion had moderate hepatocyte degeneration, dilation of central veins and proliferation of sinusoidal kupfer cells. This is similar to the findings of Karimi et al. (2014), who reported mild congestion in central veins and sinusoidal abnormality when Merino lambs were fed tanninferous sorghum-based diets. Hervas et al. (2003) reported moderate hydropic degeneration in the hepatocytes of sheep dosed intra-ruminally with $3.0 \mathrm{~g}$ quebracho tannin extracts. The results indicate that the livers of the goats fed $V$. karroo leaf meal up to $30 \%$ were not adversely affected. However, severe hepatocyte degeneration was noticed in the liver of goats fed diets with 40 or $50 \%$ V. karroo leaf meal. Lesions associated with natural oak toxicosis characterized by hepatic and renal damage have been reported in cattle (Spier et al., 1987). Histological changes such as shrinkage of hepatocyte, degeneration and necrosis of hepatocytes around the central veins and degeneration of some hepatic sinusoids have been reported in lambs fed high tanninferous sorghum grain diets (Karimi et al., 2014). The present results showed that high $V$. karroo leaf meal inclusion levels of 40 or $50 \%$ in the ration may cause damages to the liver of bucks and hence such inclusion levels are not recommended.

The kidney is also an important organ for elimination of waste or toxic materials in the body. Exposure of the kidney to toxins may cause serious damages to this organ (Junqueira and Carneiro, 2003). However, the present study showed that the experimental diets did not cause any serious damage to the kidneys of the goats. This agrees with the findings of Silanikove et al. (1996) who reported no damage to the kidneys of goats fed tannin-containing leaves. On the contrary, Karimi et al. (2014) observed that high levels of sorghum grains in the diets induced histological changes in the kidneys of sheep. Some ruminants on tanninferous forage tend to develop adapted rumen microorganisms that detoxify plant secondary metabolites (Alonso-Diaz et al., 2010). The detoxification process may, however, cause adverse effects in ruminants as a consequence of increased enzymatic demand in the liver, kidney, gut mucosa and other tissues (Van Soest, 1994). 


\section{Conclusions}

Dietary $V$. karroo leaf meal levels in the present study did not improve feed intake, growth performance, carcass weight and carcass components of bucks. This may be an indication that the diets supplied adequate nutrients for growth of the goats. Vachelia karroo leaf meal did not adversely affect meat tenderness, juiciness, flavor, taste, aroma and overall acceptability. This is good for goat meat consumers, and requires further studies to confirm the responses. Meat $\mathrm{pH}$, color, water-holding capacity, shear force, cooking loss and dressing percentage were not influenced by high and low V. karroo leaf meal levels. This is an indication that the diets had no adverse effects on these parameters. However, the effect of $V$. karroo on meat lightness was variable, depending on the inclusion level but without any recognizable pattern.

Vachelia karroo leaf meal inclusion levels of 20, 25 or $30 \%$ did not have adverse effects on livers and kidneys of bucks. However, severe hepatocyte degeneration was noticed in the liver of bucks fed diets with $V$. karroo leaf meal inclusion levels of 40 or $50 \%$. Thus, V. karroo leaf meal inclusion levels of 20 to $30 \%$ are suggested. However, more detailed studies are recommended to confirm these results.

Acknowledgements. The financial assistance of the National Research Foundation (NRF) towards this research is hereby acknowledged. Opinions expressed and conclusions arrived at are those of the authors and are not necessarily to be attributed to the NRF.

Conflict of interests. The authors declare no conflict of interests.

\section{REFERENCES}

[1] AOAC (Association of Official Analytical Chemists) (2005): Official Methods of Analysis. $17^{\text {th }}$ Ed. - AOAC, Gaithersburg, MD, USA.

[2] Alonso-Diaz, M. A., Torres-Acosta, J. F. J., Sandoval-Castro, C. A., Hoste, H. (2010): Tannins in tropical tree fodders fed to small ruminants: A friendly foe? - Small Ruminant Research 89: 164-173.

[3] Babikerm, S. A., Elkhiderml, A., Shafie, S. A. (1990): Chemical composition and quality attributes of goat meat and lamb. - Meat Science 28: 273-277.

[4] Bakare, A. G., Chimonyo, M. (2011): Seasonal variation in time spent foraging by indigenous goat genotypes in a semi-arid rangeland in South Africa. - Livestock Science 135: 251-256.

[5] Barnes, R. D., Filer, D. L., Milton, S. J. (1996): Acacia karroo: Monograph and Annotated Bibliography. - Tropical Forestry Papers, Oxford Forestry Institute, Oxford, UK.

[6] Baublits, R. T., Brown, A. H., Pohlman, F. W., Johnson, Z. B., Onks, D. O., Loveday, H. D. (2004): Carcass and beef colour characteristics of three biological types of cattle grazing cool-season forages supplemented with soy hulls. - Meat Science 68: 297-303.

[7] Bray, A. R., Graafbuis, A. E., Chrystall, B. B. (1989): The cumulative effect of nutritional, shearing and pre-slaughter washing stresses on the quality of lamb meat. Meat Science 25: 59-67.

[8] Brown, D., Ng'ambi, J. W. (2017): Effect of polyethylene glycol 4000 supplementation on the performance of yearling male Pedi goats fed dietary mixture levels of Acacia karroo leaf meal and Seteria verticillata grass hay. - Tropical Animal Health and Production 49: 1051-1057.

[9] Brown, D., Ng'ambi, J. W., Norris, D. (2017): Effect of tanniniferous Acacia karroo leaf meal inclusion level on feed intake, digestibility and live weight gain of goats fed a 
Setaria verticillata grass hay-based diet. - Journal of Applied Animal Research. DOI: 10.1080/09712119.2017.1289939.

[10] Cheeke, P. R. (1988): Toxicity and metabolism of pyrrolizidine alkaloids. - Journal of Animal Science 66: 2343-2350.

[11] Chrystall, B., Culioli, J., Honikel, K. O., Möller, A. J., Purslow, P., Schwägele, F., Shorthose, R., Uytterhaegen, L. (1994): Recommendation of reference methods for assessment of meat tenderness. - Proceedings of the $40^{\text {th }}$ International Congress of Meat Science and Technology. The Netherlands, pp. 1-7.

[12] Cross, H. R., Moen, R., Stanfield, M. S. (1978): Training and testing of judges for sensory analysis of meat quality. - Food Technology 32(7): 48-54.

[13] Das, A., De, D., Katole, S. (2011): Effect of partial replacement of concentrates with Barhar (Artocarpus lakocha) leaves on growth performance of kids fed a mixed jungle grass-based diet. - Asian-Australasian Journal of Animal Science 24(1): 45-55.

[14] Ding, W., Kou, L., Cao, B., Wei, Y. (2010): Meat quality parameters of descendants by hybridization of boar and Guanzhong dairy goat. - Meat Science 84: 323-328.

[15] Dludla, S. P. (2010): The effect of condensed tannins on goats' body weight. - MSc Thesis. Department of Agriculture, Faculty of Science and Agriculture, University of Zululand.

[16] Ganong, W. F. (2005): Review of Medical Physiology. $18^{\text {th }}$ Edition. - Appleton and Lange, Simon and Schister Company, USA, pp 150-160.

[17] Gilboa, N. (1995): Negative effects of tannin on livestock and their neutralization. - PhD Thesis. The Hebrew University of Jerusalem, Jerusalem, Israel.

[18] Gxasheka, M., Thobela, L. T., Ning, Q., Zhi-Chao, L. (2015): An overview of tannins rich plants as alternative supplementation on ruminant animals: a review. - International Journal of Agricultural Research and Review 3(6): 343-349.

[19] Hervás, G., Pérez, V., Giráldez, F. J., Mantecón, A. R., Almar, M. M., Frutos, P. (2003): Intoxication of sheep with quebracho tannin extract. - Journal of Comparative Pathology 129: 44-54.

[20] Holechek, J. L., Munshikpu, A. V., Saiwana, L., Nuiiez-Hemandez, G., Valdez, R., Wallace, J. D., Cardenas, M. (1990): Influences of six shrubs diets varying in phenol content on intake and nitrogen retention by goats. - Tropical Grasslands 24: 91-98.

[21] Jamala, G. Y., Tarimbuka, I. L., Moris, D., Mahai, S. (2013): The scope and potentials of fodder trees and shrubs in agroforestry. - IOSR Journal of Agriculture and Veterinary Science 5: 11-17.

[22] Junqueira, L., Carneiro, J. (2003): Basic Histology: Text and Atlas. 10 ${ }^{\text {th }}$ Edition. McGraw Hill, New York.

[23] Kaitho, R. J., Umunna, N. N., Nsahlai, I. V., Tamminga, S., Van Bruchem, J., Hanson, J., Van DeWouw, M. (1996): Palatability of multipurpose tree species: Effect of species and length of study on intake and relative palatability by sheep. - Agroforestry Systems 33: 249-261.

[24] Karimi, H., Hossein, D. K., Hosseinkhani, A. (2014): Histological effects of different levels of sorghum grain on the liver and kidney of Ghezel $\times$ Arkhar-Merino crossbred lambs. - Animal and Veterinary Sciences 2(4): 130-134.

[25] Lamy, E., Rawel, H., Schweigert, F. J., Capela Silva, F., Ferreira, A., Rodigues, C. A., Antunes, C., Almeida, A. M., Varela Coelho, A., Sales-Baptista, E. (2011): The effect of tannins on Mediterranean ruminant ingestive behaviour: The role of the oral cavity. Molecules 16: 2766-2784.

[26] Mahgoub, O., Kadim, I. T., Tageldin, M. H., Al-Marzooq, W. S., Halaf, S. Q., Ambu, A. A. (2008): Clinical profile of sheep fed non-conventional feeds containing phenols and condensed tannins. - Small Ruminant Research 78: 115-122.

[27] Mapiye, C., Chimonyo, M., Dzama, K., Strydom, P. E., Marufu, M. C., Muchenje, V. (2009): Nutritional status, growth performance and carcass characteristics of Nguni steers supplemented with Acacia karroo leaf-meal. - Livestock Science 126: 206-214. 
[28] Mapiye, C., Chimonyo, M., Dzama, K., Strydom, P. E., Muchenje, V. (2010): Meat quality attributes of Nguni steers supplemented with Acacia karroo leaf-meal. - Meat Science 8: 621-627.

[29] Marume, U. (2010): Effect of Acacia karroo on growth and meat quality of indigenous goats. - PhD Thesis. University of Fort Hare, South Africa.

[30] Mbatha, K. R., Downs, C. T., Nsahlai, I. V. (2002): The effects of graded levels of dietary tannin on the epithelial tissue of the gastrointestinal tract and liver and kidney masses of Boer goats. - Journal of Animal Science 74: 579-586.

[31] McDonald, P., Edwards, R. A., Greenhalgh, J. F. D., Morgan, C. A., Sinclair, L. A., Wilkinson, R. G. (2011): Animal Nutrition. Seventh Edition. - Prentice Hall, London.

[32] Mokoboki, H. K., Ndlovu, L. R., Ng'ambi, J. W., Malatje, M. M., Nikolova, R. V. (2005): Nutritive value of Acacia tree foliage growing in the Limpopo Province of South Africa. - South African Journal of Animal Science 35: 221- 228.

[33] Moon, S. H., Oh, M. R., Cheong, S. H., Jeon, B. T., Kim, S. J., Sung, S. H., Park, J. H. (2014): Effect of lemon grass supplementation on antioxidant enzyme activity within the longissimus muscle of Hanwoo (Bos taurus coreanae) heifer. - Research Journal of Pharmaceutical, Biological and Chemical Sciences 5(5): 718-723.

[34] Mostert, A. C. (2007): Meat quality of kudu (Tragelaphus strepsiceros) and impala (Aepyceros melampus). - MSc Thesis, University of Stellenbosch, South Africa.

[35] Moyo, B., Oyedemi, S., Masika, P. J., Muchenje, V. (2012): Polyphenolic content and antioxidant properties of Moringa oleifera extracts and enzymatic activity of liver from goats supplemented with Moringa oleifera leaves/sunflower seed cake. - Meat Science 91: 441- 447.

[36] Muir, J. (2011): The multi-faceted role of condensed tannins in the goat ecosystem. Small Ruminant Research 98(1): 115-120.

[37] Ng'ambi, J. W., Gwanzura, T., Brown, D., Ginindza, M. M. (2018): Effects of mixture level of sorghum hay with forage legumes on performance and blood metabolites of yearling indigenous Pedi bucks. - Applied Ecology and Environmental Research 16(3): 2197-2212.

[38] Ngambu, S., Muchenje, V., Marume, U. (2012): The effect of Acacia karroo supplementation and thermal preparation on meat sensory characteristics of the indigenous Xhosa lop-eared goat genotype. - African Journal of Biotechnology 11: 12878-12884.

[39] Ngambu, S., Muchenje, V., Marume, U. (2013): Effect of Acacia karroo supplementation on growth, ultimate $\mathrm{pH}$, colour and cooking losses of meat from indigenous Xhosa Lopeared goats. - Asian-Australasian Journal of Animal Science 26: 128-133.

[40] Porter, L. J., Hristich, L. N., Chan, B. G. (1986): The conversion of procyanidins and prodelphinidins to cyanidins and delphinidins. - Phytochemistry 25: 223-230.

[41] Priolo, A., Vasta, V. (2007): Effects of tannin-containing diets on small ruminant meat quality. - Italian Journal of Animal Science 6(suppl. 1): 527-530.

[42] Priolo, A., Micol, D., Agabriel, J. (2001): Effects of grass feeding systems on ruminant meat color and flavor. A review. - Animal Research 50: 185-200.

[43] Priolo, A., Bella, M., Lanza, M., Galofaro, V., Biondi, L., Barbagallo, D., Ben Salem, H., Pennisi, P. (2005): Carcass and meat quality of lambs fed fresh sulla (Hedysarum coronarium L.) with or without polyethylene glycol or concentrate. - Small Ruminant Research 59: 281-288.

[44] Qwele, K., Hugo, A., Oyedemi, S. O., Moyo, B., Masika, P. J., Muchenje, V. (2013): Chemical composition, fatty acid content and antioxidant potential of meat from goats supplemented with Moringa (Moringa oleifera) leaves, sunflower cake and grass hay. Meat Science 93(3): 455-462.

[45] Sánchez-Chardi, A., Marques, C. C., Gabriel, S. I., Capela-Silva, F., Cabrita, A. S., LópezFuster, M. J., Nadal, J., Mathias, M. L. (2008): Haematology, genotoxicity, 
enzymatic activity and histopathology as biomarkers of metal pollution in the shrew Crocidura russula. - Environmental Pollution 156: 1332-1339.

[46] Sánchez-Chardi, A., Ciro Alberto, O. R., Jacint, N. (2009): Metals in liver and kidneys and the effects of chronic exposure to pyrite mine pollution in the shrew Crocidura russula inhabiting the protected wetland of Doñana. - Chemosphere 76: 387-394.

[47] SAS (2010): User's Guide: Statistics. - SAS Institute Inc., Cary, MC, USA.

[48] Silanikove, N., Gilboa, N., Nir, I., Perevolotsky, A., Nitsan, Z. (1996): Effect of a daily supplementation of polyethylene glycol on intake and digestion of tannin-containing leaves (Quercus calliprinos, Pistacia lentiscus and Ceratonia siliqua) by goats. - Journal of Agricultural and Food Chemistry 44: 199-205.

[49] Solaiman, S., Thomas, J., Dupre, Y., Min, B. R., Gurung, N., Terrill, T. H., Haenlein, G. F. W. (2010): Effect of feeding sericea lespedeza (Lespedeza cuneata) on growth performance, blood metabolites, and carcass characteristics of Kiko crossbred male kids. - Small Ruminant Research 93: 149-156.

[50] Spier, S. J., Smith, B. P., Seawright, P., Norman, A. A., Ostrowski, S. R., Oliver, M. N. (1987): Oak toxocosis in cattle in northern California: clinical and pathologic findings. Journal of the American Veterinary Medical Association 191: 958-964.

[51] Trout, G. R. (1988): Techniques for measuring water-binding capacity in muscle foods - a review of methodology. - Meat Science 23: 235-252.

[52] Van Soest, P. (1994): Nutritional Ecology of the Ruminant. $2^{\text {nd }}$ Edition. - Cornell University Press, London.

[53] Velasco, V., Salinas, P. W. (2011): Improving meat quality through natural antioxidants. - Chilean Journal of Agricultural Research 71(2): 313-322.

[54] Verna, M., Pace, V., Settineri, D., Di Giacomo, A., Nanni, A. (1989): Use of sorghum in different content of tannins in animal lambs. II. Considerations on the dissection of the thigh, on the quality of the meat and on the histological and histochemical findings of the organs. - Ann Ist Sper Zootec 22(1): 1-14.

[55] Waterman, P. G., Mole, S. (1994): Analysis of Phenolic Plant Metabolites. - Blackwell Scientific Publications, Oxford, UK.

[56] Wright, C. (2015): The effects of phytochemical tannin-containing diets on animal performance and internal parasite control in meat goats. - MSc Thesis. College of Agriculture, Environment and Nutrition Sciences, Tuskegee University. 